\title{
PENGARUH BAHAN PENGEKSTRAK TERHADAP KARAKTERISTIK EKSTRAK SENYAWA FUNGSIONAL DARI KULIT BUAH NAGA MERAH (Hylocereus polyrhizus)
}

\author{
Nana Sutisna Achyadi \\ Asep Dedy Sutrisno \\ Azizah Fauziah \\ Program Studi Teknologi Pangan, Fakultas Teknik, Universitas Pasundan, Jl. Dr.Setiabudi No 93, Bandung, 40153, \\ Indonesia \\ E-mail : nanasutisnaachyadi@unpas.ac.id
}

\begin{abstract}
The purpose of this study is to determine the use of extracting materials suitable for dragon fruit skin extraction so that the functional compound (anthocyanin) obtained optimally. The research method consisted of preliminary research and main research. Preliminary research was conducted to determine the maceration method (maceration and maceration modification with agitator) to be used in the main research and raw material analysis. The main research is conducted to determine the appropriate extracting agent (various types of acids and mixtures). The experimental design used in the study was Randomized Block Design (RAK) with 1x6 factorial pattern with 4 replications. Response variable in this research is physical response include analysis of dye and calculation of rendement and chemical response which include determination of acidity level $(\mathrm{pH})$, vitamin $\mathrm{C}$ content analysis, water content analysis, and antioxidant activity analysis. The result of preliminary research is obtained that the maceration method chosen is the usual maceration method and the result of raw material analysis which includes the vitamin $\mathrm{C}$ level of 184,937 mg vitamin C / 100 gram sample; analysis of dye where $\mathrm{L} * 37.56 \mathrm{a} * 9.29 \mathrm{~b} *-0.31$; and acidity level $(\mathrm{pH}) 4.73$. While based on the results from the main study obtained that the selected extracting material is $2 \%$ tartrate $(\mathrm{w} / \mathrm{v})$. Response result obtained that is yield $19,09 \%$; dye analysis with $\mathrm{L} * 48,12 \mathrm{a} * 31.02$ and $\mathrm{b} * 2,70$; acidity level $(\mathrm{pH}) 0.73$; rate of water 6,3\%; vitamin C levels of $167.63 \mathrm{mg}$ vitamin C / 100 gram samples; as well as antioxidant activity of 10,242.83 ppm.

Keywords: Dragon Fruit, Extracting Material, Anthocyanin
\end{abstract}

\section{Pendahuluan}

Pada masa ini, buah-buahan mulai banyak dikembangkan untuk diolah menjadi produk yang lebih bermanfaat atau disebut produk fungsional. Dimana produk fungsional ini tidak hanya memiliki kelebihan nilai guna, tetapi juga nilai gizi dan nilai ekonomi.

Buah Naga atau Dragon Fruit (buah dari tanaman Hylocereus) merupakan buah yang mulai banyak dibudidayakan di Indonesia. Selain memiliki rasa yang asam manis menyegarkan dan memiliki tampilan yang menarik, buah naga juga memiliki beragam manfaat untuk kesehatan. Buah naga terdiri dari berbagai macam varietas buah seperti buah naga merah dengan daging buah putih (Hylocereus undatus), buah naga kuning dengan daging buah putih (Selenicereus megalanthus), buah naga merah muda dengan daging buah merah (Hylocereus polyrhizus), dan buah naga dengan warna buah sangat merah (Hylocereus costaricensis). (Chayati, dkk. 2011).

Buah naga merah muda dengan daging buah merah (Hylocereus polyrhizus) merupakan buah naga yang paling sering dijumpai di masyarakat. Berbagai olahan buah naga merah ini bermacam-macam seperti jus buah naga, fruit leather buah naga merah, selai buah naga merah, dan sirup buah naga. Namun, pemanfaatan dari limbah kulit buah naga belum banyak dilakukan oleh masyarakat luas pada umumnya. Kulit buah naga banyak dimanfaatkan di industri seperti pewarna alami pada makanan maupun minuman. Dalam bidang farmakologi, kulit buah naga dapat dijadikan sebagai obat herbal alami yang dapat bermanfaat sebagai antioksidan. Selain kaya akan vitamin C, vitamin E, vitamin A, piridoksin, alkaloid, terpenoid, flavonoid, tiamin, niasin, piridoksin, kobalamin, fenolik, karoten, serta fitoalbumin. Kulit buah naga juga mengandung antosianin tinggi yang memiliki aktivitas antioksidan lebih besar dibandingkan aktivitas antioksidan pada daging buahnya.

Menurut Nurliyana dkk. (2010) dalam Putri dkk. (2015) menyatakan bahwa dalam $1 \mathrm{mg} / \mathrm{ml}$ kulit buah naga merah mampu menghambat $83,48 \pm 1,02 \%$ radikal bebas, sedangkan pada daging buah naga hanya mampu menghambat radikal bebas sebesar 27,45 $\pm 5,03 \%$.

Antosianin merupakan pigmen yang menyebabkan buah, sayur, atau tanaman hias berwarna merah, biru, dan ungu. Senyawa ini termasuk dalam golongan flavonoid. Degradasi antosianin dapat terjadi selama proses ekstraksi, pengolahan makanan, dan penyimpanan. Faktor-faktor yang mempengaruhi stabilitas antosianin yaitu adanya modifikasi pada struktur spesifik antosianin (glikosilasi, asilasi dengan asam alifatik atau aromatik), $\mathrm{pH}$, suhu, cahaya, keberadaan ion logam, oksigen, kadar gula, dan enzim. (Andarwulan, 2012).

Antosianin merupakan senyawa yang bersifat termolabil (peka terhadap suhu tinggi). Selain itu keadaan yang semakin asam menyebabkan semakin banyak dinding sel vakuola yang pecah sehingga pigmen antosianin semakin banyak yang terekstrak. Sehingga diperlukan perlakuan yang benar untuk 
mengoptimalkan perolehan antosianin dari kulit buah naga.

Berdasarkan latar belakang tersebut, ekstraksi kulit buah naga akan lebih stabil apabila ditambahkan asam. Sehingga pada penelitian ini akan digunakan beberapa jenis asam dan campuran asam sebagai bahan pengekstrak dengan konsentrasi tertentu. Dimana proses ekstraksi kulit buah naga dilakukan dengan metode maserasi.

\section{Metode Penelitian}

Bahan yang digunakan dalam penelitian ini adalah kulit buah naga merah berasal dari Pasar Geger Kalong Kota Bandung. Buah Naga tersebut berumur 1,52 tahun. Selain itu bahan lain yang digunakan adalah Aquadest, Asam Sitrat, Asam Tartrat, Asam Asetat Glasial, Maltodekstrin dan $\mathrm{NaHCO}$ (Natrium Bikarbonat. Bahan yang digunakan dalam analisis adalah Analisis Aktivitas Antioksidan (metanol dan larutan DPPH), Penentuan Kadar Vitamin C dengan Volumetri (Amilum, Arsenik Trioksida (As2O3), $\mathrm{NaOH}$ $1 \mathrm{~N}$, Metil Merah, HCl, Natrium Bikarbonat (NaHCO3), dan Iodium (I2) 0,01N).

Alat yang digunakan dalam penelitian adalah Blender Philips Type HR-2116, Neraca Analitik Mettler Toledo PL202-S, Magnetic Stirrer, Rotavapor R-3 Buchi, Gelas Ukur Pyrex, Labu Ukur 100 ml Iwaki Pyrex, Toples Plastik Lion Star, Tunnel Dryer, Botol Plastik Coklat, Kain Waring, Pisau, Batang Pengaduk, Talenan, dan Saringan. Alat yang digunakan untuk analisis adalah Gelas Kimia $500 \mathrm{ml}$ Asahi Glass, Neraca Analitik Mettler Toledo PL202-S, Spektrofotometer UV-Visible, Oven Memmert ${ }^{\circledR}$, Eksikator Pyrex TM, Digital Colorimeter, Buret Pyrex Iwaki, Labu Ukur 100 ml Iwaki Pyrex, pH Meter, Pipet Tetes, Pipet Seukuran, Filler, Klem dan Statif, Penjepit Besi, dan Kaca Arloji.

Penelitian ini terdiri dari dua tahap, yaitu penelitian pendahuluan dan penelitian utama. Penelitian pendahuluan terdiri dari dua tahapan, tahap pertama yaitu analisis bahan baku yang meliputi analisis kadar vitamin $\mathrm{C}$, analisis zat warna, dan tingkat keasaman $(\mathrm{pH})$. Tahap kedua adalah penentuan metode yang akan digunakan untuk penelitian utama yaitu metode maserasi dan metode maserasi dengan modifikasi pengaduk (menggunakan alat magnetic stirrer). Penelitian utama yaitu menentukan bahan pengekstrak yang sesuai dalam ekstrak senyawa fungsional dari kulit buah naga. Selanjutnya dilakukan pengukuran tingkat keasaman $(\mathrm{pH})$, perhitungan rendemen ekstrak, penentuan kadar air, analisis aktivitas antioksidan dengan metode DPPH, penentuan kadar vitamin C dengan metode volumetri (iodimetri), dan analisis zat warna dengan menggunakan digital colorimeter. Penelitian utama terdiri dari rancangan perlakuan, rancangan percobaan, rancangan analisis, dan rancangan respon. Rancangan perlakuan pada penelitian utama terdiri dari satu faktor yaitu pengaruh bahan pengekstrak yang meliputi 6 taraf, antara lain : e1 = larutan asam sitrat $2 \%(\mathrm{w} / \mathrm{v})$ e2 $=$ larutan asam tartrat $2 \%(\mathrm{w} / \mathrm{v})$ e $3=$ larutan asam asetat $2 \%(\mathrm{v} / \mathrm{v})$ e $4=$ larutan asam sitrat dan asam tartrat $2 \%$ e $5=$ larutan asam sitrat dan asam asetat $2 \%$ e6 = larutan asam tartrat dan asam asetat 2\%. Rancangan Percobaan Model rancangan percobaan yang digunakan dalam penelitian ini adalah Rancangan Acak Kelompok (RAK) dengan pola faktorial 1 × 6 × 4 dimana masingmasing rancangan terdiri dari 1 (satu) faktor dan 6 (enam) taraf dengan 4 (empat) kali pengulangan, sehingga diperoleh 24 satuan perobaan.

Rancangan respon dalam penelitian ini meliputi respon fisika dan respon kimia. Respon fisika yang diuji terhadap ekstrak kulit buah naga yaitu perhitungan rendemen ekstrak kulit buah naga dan analisis zat warna menggunakan alat digital colorimeter. Respon kimia yang diuji terhadap ekstrak kulit buah naga adalah penentuan kadar air ekstrak, penentuan tingkat keasaman $(\mathrm{pH})$, penentuan kadar vitamin $\mathrm{C}$ dengan metode volumetri (iodimetri), serta analisis aktivitas antioksidan dengan metode DPPH.

\section{Hasil dan Pembahasan \\ Hasil Penelitian Pendahuluan}

Penelitian pendahuluan yang dilakukan terlebih dahulu adalah analisis bahan baku yaitu analisis kadar vitamin $\mathrm{C}$, analisis zat warna, serta analisis tingkat keasaman $(\mathrm{pH})$ yang terdapat pada kulit buah naga merah segar sebelum diolah menjadi produk ekstrak senyawa fungsional kulit buah naga. Penelitian pendahuluan yang kedua yaitu penentuan metode maserasi yang akan digunakan pada penelitian utama. Variabel respon yang dilakukan adalah analisis kadar vitamin $\mathrm{C}$ dengan metode iodimetri, analisis kadar air dengan metode gravimetri serta analisis zat warna dengan colorimeter dimana akan diperoleh metode maserasi terbaik.

Hasil analisis bahan baku kulit buah naga merah pada penelitian pendahuluan dapat dilihat pada Tabel 1 .

Tabel 1. Hasil Analisis Bahan Baku

\begin{tabular}{|c|c|}
\hline Analisis & Hasil \\
\hline \multirow{2}{*}{ Kadar Vitamin C } & $\begin{array}{c}184,937 \text { mg vitamin } \\
\text { c/100 gram sampel }\end{array}$ \\
\hline \multirow{2}{*}{ Zat Warna } & $\mathrm{L}^{*}=37,56$ \\
& $\mathrm{a}^{*}=9,29$ \\
$\mathrm{~b}^{*}=-0,31$ \\
\hline $\mathrm{pH}$ & 4,73 \\
\hline
\end{tabular}

Analisis bahan baku ini dilakukan untuk mengetahui secara pasti kandungan nutrisi yang terdapat pada kulit buah naga sehingga dapat diketahui perubahan kandungan nutrisi sebelum dan setelah diolah menjadi produk ekstrak kulit buah naga merah.

Penentuan metode maserasi yang akan digunakan pada penelitian utama akan dipilih berdasarkan hasil dari analisis kadar vitamin $\mathrm{C}$, analisis kadar air dan analisis zat warna. Berdasarkan data hasil ketiga analisis tersebut, diperoleh data seperti pada Tabel 2. 
Tabel 2. Hasil Analisis Penentuan Metode Maserasi

\begin{tabular}{|c|c|c|c|}
\hline \multirow{2}{*}{ No. } & \multirow{2}{*}{ Analisis } & \multicolumn{2}{|c|}{ Hasil } \\
\cline { 3 - 4 } & & $\begin{array}{c}\text { Maserasi } \\
\text { Biasa (A1) }\end{array}$ & $\begin{array}{c}\text { Maserasi } \\
\text { Modifikasi (A2) }\end{array}$ \\
\hline \multirow{2}{*}{1.} & Kadar Vitamin C & $\begin{array}{c}103,56 \mathrm{mg} \\
\text { vitamin c/100 } \\
\text { gram sampel }\end{array}$ & $\begin{array}{c}94,93 \mathrm{mg} \text { vitamin } \\
\text { c/100 gram } \\
\text { sampel }\end{array}$ \\
\hline 2. & Kadar Air & $5 \%$ & $9 \%$ \\
\hline 3. & Analisis Zat Warna & $\begin{array}{c}\mathrm{L}^{*}=48,91 \mathrm{a}^{*} \\
=37,54 \mathrm{~b}^{*}=\end{array}$ & $\mathrm{L}^{*}=40,73$ \\
& & $-2,92$ & $33,78 \mathrm{~b}^{*}=$ \\
& & & 7,86 \\
\hline
\end{tabular}

Vitamin C pada buah bisa hilang secara terus menerus selama pengolahan, misalnya selama blansing dan pencucian, pemotongan dan penggilingan. Paparan udara pada jaringan-jaringan akan menyebabkan hilangnya vitamin $\mathrm{C}$ akibat oksidasi. Umumnya kehilangan vitamin $\mathrm{C}$ terjadi apabila jaringan dirusak dan kontak dengan udara. Selama penyimpanan dalam keadaan beku pun terjadi kehilangan vitamin C. Makin tinggi suhu penyimpanan makin besar terjadinya kerusakan zat gizi. Dalam bahan pangan beku kehilangan yang lebih besar dijumpai terutama pada vitamin C daripada vitamin yang lain. (Rohanah, 2002).

Kadar vitamin C pada sampel A2 berkurang selama proses maserasi yang dilakukan dengan modifikasi pengaduk (stirrer) akibat adanya pengadukan. Sehingga kadar vitamin C pada sampel A2 lebih rendah dibandingkan dengan sampel A1 yang hanya dilakukan maserasi biasa. Berdasarkan analisis kadar air apabila dibandingkan dengan SNI 01-43201996 bahwa kadar air untuk minuman serbuk adalah 3 5\% sehingga sampel A1 sesuai dengan SNI dibandingkan dengan sampel A2 Berdasarkan hasil analisis zat warna terhadap sampel ekstrak kulit buah naga diperoleh bahwa sampel A1 memiliki nilai $\mathrm{L}^{*}$ (Lightness) lebih rendah dibandingkan dengan sampel A2 yang cenderung memiliki warna lebih terang.

Apabila dibandingkan dengan kulit buah naga segarnya, sampel A1 lebih sedikit mengalami perubahan kecerahan warna dibandingkan dengan sampel A2. Berdasarkan hasil analisis zat warna terhadap nilai a* (nilai yang mengkoordinasikan warna merah/hijau) diperoleh bahwa sampel A1 cenderung memiliki warna yang lebih merah dibandingkan dengan sampel A2 maupun kulit buah naga segarnya. Sedangkan berdasarkan hasil analisis zat warna terhadap nilai $\mathrm{b}^{*}$ (nilai yang mengkoordinasikan warna kuning/biru) diperoleh bahwa sampel A1 memiliki warna yang lebih biru dibandingkan dengan sampel A2 maupun kulit buah naga segarnya. Hal tersebut disebabkan karena proses ekstraksi maserasi yang mengakibatkan zat warna akan terisolasi dengan baik. Berdasarkan ketiga analisis yang dilakukan, sampel A1 yang diberikan perlakuan maserasi biasa memiliki kadar vitamin $\mathrm{C}$ lebih tinggi dibandingkan dengan sampel A2 yang dberikan perlakuan maserasi modifikasi dengan pengaduk (stirrer) yaitu sebesar $103,56 \mathrm{mg}$ vitamin C/100 gram sampel. Kadar air sampel A1 memenuhi standar SNI yaitu 5\% dibandingkan dengan sampel A2.
Dan berdasarkan analisis zat warna, sampel A2 memiliki warna yang cenderung lebih gelap, lebih merah, dan lebih biru dibandingkan dengan sampel A2. Sehingga metode maserasi biasa merupakan metode maserasi terpilih yang akan digunakan pada penelitian utama.

\section{Hasil Penelitian Utama}

Penelitian utama yaitu menentukan bahan pengekstrak yang sesuai dalam ekstrak senyawa fungsional dari kulit buah naga. Selanjutnya dilakukan pengukuran tingkat keasaman $(\mathrm{pH})$, perhitungan rendemen ekstrak, penentuan kadar air, analisis aktivitas antioksidan dengan metode DPPH, penentuan kadar vitamin $\mathrm{C}$ dengan metode volumetri (iodimetri), dan analisis zat warna dengan menggunakan digital colorimeter

\section{Rendemen}

Menurut Fennema (1976), rendemen adalah perbandingan antara berat bahan dengan hasil yang diperoleh. Rendemen yang nilainya kecil belum tentu memiliki produk dengan mutu yang rendah. Begitu pula dengan rendemen yang nilainya besar, belum tentu produk tersebut memiliki nilai mutu yang baik.

Berdasarkan hasil analisis variansi (ANAVA) menunjukkan bahwa bahan pengekstrak berpengaruh nyata terhadap rendemen ekstrak senyawa fungsional kulit buah naga merah. Hasil uji lanjut duncan dapat dilihat pada Tabel 3 .

Tabel 3. Pengaruh Bahan Pengekstrak Terhadap Rendemen

\begin{tabular}{|c|c|}
\hline Bahan Pengekstrak & $\begin{array}{c}\text { Rata-Rata Rendemen } \\
(\mathbf{\%})\end{array}$ \\
\hline e1 (Larutan Asam Sitrat) & $20,8 \mathrm{~b}$ \\
\hline $\begin{array}{c}\text { e2 (Larutan Asam } \\
\text { Tartrat) }\end{array}$ & $26,0 \mathrm{~d}$ \\
\hline $\begin{array}{c}\text { e3 (Larutan Asam } \\
\text { Asetat) }\end{array}$ & $19,7 \mathrm{a}$ \\
\hline $\begin{array}{c}\text { e4 (Larutan Asam Sitrat } \\
\text { dan Asam Tartrat) }\end{array}$ & $22,1 \mathrm{c}$ \\
\hline $\begin{array}{c}\text { e5 (Larutan Asam Sitrat } \\
\text { dan Asam Asetat }\end{array}$ & $21,1 \mathrm{bc}$ \\
\hline $\begin{array}{c}\text { e6 (Larutan Asam Tartrat } \\
\text { dan Asam Asetat) }\end{array}$ & $21,7 \mathrm{bc}$ \\
\hline
\end{tabular}

Berdasarkan pada Tabel 3, rendemen hasil ekstraksi kulit buah naga dengan menggunakan berbagai bahan pengekstrak memberikan hasil yang berbeda nyata. Hal ini dipengaruhi oleh tingkat keasaman dari bahan pengekstrak selama proses ekstraksi berlangsung. Penggunaan asam tartrat diduga lebih kuat menghancurkan partikelpartikel padatan kulit buah naga selama ekstraksi dibandingkan dengan larutan bahan pengekstrak lainnya.

Keadaan tersebut mengakibatkan banyaknya dinding-dinding sel yang rusak atau hancur sehingga memudahkan pelarut untuk berdifusi ke dalam sel-sel kulit buah naga, mengakibatkan semakin banyak 
pigmen warna yang larut di dalam larutan asam tartrat. Dinding sel tanaman tersusun dari polimer karbohidrat yaitu pektin, selulosa, hemiselulosa, dan lignin (Winarno, 1997).

Polimer ini terdiri dari berbagai monosakarida yang terikat satu dengan yang lain melalui ikatan glikosidik. Ikatan glikosidik mudah diputus oleh suatu katalis asam (Sun dan Cheng, 2005). Hal ini menyebabkan rendemen kasar pigmen warna yang dihasilkan berbeda nyata untuk keenam perlakuan.

Selain itu, penambahan bahan pengekstrak dapat mempengaruhi kepolaran dari pelarut yang digunakan (aquadest) sehingga ekstrak yang dihasilkan diduga memiliki tingkat kepolaran yang berbeda dan keadaan ini akan memberikan pengaruh terhadap hasil dari rendemen ekstrak yang diperoleh (Tensiska, 2007).

\section{Analisis Zat Warna}

Penentuan mutu bahan pangan pada umumnya tergantung pada beberapa faktor diantaranya adalah cita rasa, tekstur, nilai gizi, serta sifat mikrobiologis. Tetapi terdapat beberapa faktor lain yang perlu dipertimbangkan secara visual misalnya warna akan tampil lebih dahulu dan terkadang akan sangat menentukan mutu bahan pangan. Zat warna makanan merupakan penentu nilai gizi suatu bahan makanan. Selain sebagai faktor yang ikut menentukan mutu, warna juga dapat digunakan sebagai indikator kesegaran atau kematangan. Baik tidaknya pengolahan dapat ditandai dengan adanya warna yang seragam dan merata. (Trinita, 2014)

Colorimeter merupakan sebuah alat yang digunakan untuk mengukur warna. Alat ini sensitif terhadap cahaya yang diukur dan berapa banyak warna yang diserap oleh sebuah benda ataupun zat. Alat ini menentukan warna berdasarkan komponen merah, biru, dan hijau dari cahaya yang diserap oleh objek atau sampel.

Ditetapkan oleh Komisi Internationale de l'Eclairage (CIE), ruang warna $L^{*} a^{*} b^{*}$ dimodelkan setelah teori warna lainnya yang menyatakan bahwa dua warna tidak bisa merah dan hijau pada waktu yang sama atau kuning dan biru pada saat yang sama waktu.

Notasi $\mathrm{L}^{*}$ : menunjukkan warna akromatik putih, abu - abu dan hitam dengan nilai 0 (hitam) sampai 100 (putih) atau menunjukkan lightness (terang).

Notasi $a^{*}$ : menunjukkan warna kromatik dengan nilai 0 sampai 100 untuk warna merah, dan nilai - 80 sampai 0 untuk warna hijau.

Notasi $b^{*}$ : menunjukkan warna kromatik dengan nilai 0 sampai 70 untuk warna kuning, dan nilai - 70 sampai 0 untuk warna biru.

Berdasarkan hasil analisis variansi (ANAVA) menunjukkan bahwa bahan pengekstrak berpengaruh nyata terhadap zat warna ekstrak senyawa fungsional kulit buah naga merah. Hasil uji lanjut duncan dapat dilihat pada Tabel 4, 5, dan 6.
Tabel 4. Pengaruh Bahan Pengekstrak Terhadap Zat Warna Nilai L*

\begin{tabular}{|c|c|}
\hline Bahan Pengekstrak & $\begin{array}{c}\text { Rata-Rata Zat Warna } \\
\text { Nilai L* }\end{array}$ \\
\hline e1 (Larutan Asam Sitrat) & $46,77 \mathrm{~b}$ \\
\hline e2 (Larutan Asam Tartrat) & $48,12 \mathrm{~b}$ \\
\hline e3 (Larutan Asam Asetat) & $51,66 \mathrm{c}$ \\
\hline $\begin{array}{c}\text { e4 (Larutan Asam Sitrat dan } \\
\text { Asam Tartrat) }\end{array}$ & $46,30 \mathrm{~b}$ \\
\hline $\begin{array}{c}\text { e5 (Larutan Asam Sitrat dan } \\
\text { Asam Asetat) }\end{array}$ & $46,40 \mathrm{~b}$ \\
\hline $\begin{array}{c}\text { e6 (Larutan Asam Tartrat dan } \\
\text { Asam Asetat) }\end{array}$ & $43,91 \mathrm{a}$ \\
\hline
\end{tabular}

Tabel 5. Pengaruh Bahan Pengekstrak Terhadap Zat Warna Nilai $\mathrm{a}^{*}$

\begin{tabular}{|c|c|}
\hline Bahan Pengekstrak & $\begin{array}{c}\text { Rata-Rata Zat Warna } \\
\text { Nilai a* }\end{array}$ \\
\hline e1 (Larutan Asam Sitrat) & $24,87 \mathrm{a}$ \\
\hline e2 (Larutan Asam Tartrat) & $31,02 \mathrm{~d}$ \\
\hline e3 (Larutan Asam Asetat) & $25,94 \mathrm{~b}$ \\
\hline $\begin{array}{c}\text { e4 (Larutan Asam Sitrat dan } \\
\text { Asam Tartrat) }\end{array}$ & $29,24 \mathrm{c}$ \\
\hline $\begin{array}{c}\text { e5 (Larutan Asam Sitrat dan } \\
\text { Asam Asetat) }\end{array}$ & $25,76 \mathrm{~b}$ \\
\hline $\begin{array}{c}\text { e6 (Larutan Asam Tartrat dan } \\
\text { Asam Asetat) }\end{array}$ & $28,49 \mathrm{c}$ \\
\hline
\end{tabular}

Tabel 6. Pengaruh Bahan Pengekstrak Terhadap Zat Warna Nilai $b^{*}$

\begin{tabular}{|c|c|}
\hline Bahan Pengekstrak & $\begin{array}{c}\text { Rata-Rata Zat Warna } \\
\text { Nilai b* }\end{array}$ \\
\hline e1 (Larutan Asam Sitrat) & $3,87 \mathrm{~b}$ \\
\hline e2 (Larutan Asam Tartrat) & $2,70 \mathrm{a}$ \\
\hline e3 (Larutan Asam Asetat) & $5,55 \mathrm{c}$ \\
\hline $\begin{array}{c}\text { e4 (Larutan Asam Sitrat dan } \\
\text { Asam Tartrat) }\end{array}$ & $4,56 \mathrm{~b}$ \\
\hline $\begin{array}{c}\text { e5 (Larutan Asam Sitrat dan } \\
\text { Asam Asetat) }\end{array}$ & $5,80 \mathrm{c}$ \\
\hline $\begin{array}{c}\text { e6 (Larutan Asam Tartrat dan } \\
\text { Asam Asetat) }\end{array}$ & $5,59 \mathrm{c}$ \\
\hline
\end{tabular}

Brouillard (1982) dalam Jian Hie (2004) menyatakan bahwa dalam bentuk karbinol warna antosianin mengalami pemucatan karena pada cincin tengah telah kehilangan ikatan rangkap yang terkonjugasi, sehingga tidak dapat mengabsobsi sinar tampak.

Berdasarkan hasil penelitian, ekstraksi dengan menggunakan larutan asam tartrat memiliki rerata nilai $a^{*}$ (cenderung memiliki warna merah hingga hijau) yang lebih besar (lebih berwarna merah) dibandingkan dengan menggunakan larutan lain akibat tingkat keasaman $(\mathrm{pH})$ yang lebih rendah dibandingkan larutan lainnya. Sedangkan ekstraksi dengan menggunakan larutan asam asetat maupun campurannya memiliki nilai rerata nilai $b^{*}$ (cenderung memiliki warna biru hingga kuning) yang lebih besar (cenderung berwarna kuning) 
akibat tingkat keasaman yang lebih tinggi dibandingkan dengan larutan lainnya.

Berdasarkan rerata nilai $\mathrm{L}^{*}$, penggunaan larutan asam asetat memiliki tingkat kecerahan (lightness) yang lebih tinggi dibandingkan dengan 5 sampel lainnya. Hasil tersebut diduga akibat $\mathrm{pH}$ larutan yang lebih tinggi dibandingkan $\mathrm{pH}$ larutan lainnya sehingga menyebabkan warna ekstrak menjadi lebih terang. Sedangkan $\mathrm{pH}$ larutan yang lebih rendah menyebabkan warna ekstrak menjadi lebih pekat (gelap). (Jian Hie, 2004)

\section{Tingkat Keasaman (pH)}

Berdasarkan hasil analisis variansi (ANAVA) menunjukkan bahwa bahan pengekstrak berpengaruh nyata terhadap tingkat keasaman $(\mathrm{pH})$ ekstrak senyawa fungsional kulit buah naga merah. Hasil uji lanjut duncan dapat dilihat pada Tabel 7.

Tabel 7. Pengaruh Bahan Pengekstrak Terhadap Tingkat Keasaman $(\mathrm{pH})$

\begin{tabular}{|c|c|}
\hline Bahan Pengekstrak & $\begin{array}{c}\text { Rata-Rata Tingkat } \\
\text { keasaman }(\mathrm{pH})\end{array}$ \\
\hline e1 (Larutan Asam Sitrat) & $1,582 \mathrm{c}$ \\
\hline e2 (Larutan Asam Tartrat) & $0,985 \mathrm{a}$ \\
\hline e3 (Larutan Asam Asetat) & $3,095 \mathrm{f}$ \\
\hline $\begin{array}{c}\text { e4 (Larutan Asam Sitrat dan } \\
\text { Asam Tartrat) }\end{array}$ & $1,352 \mathrm{~b}$ \\
\hline $\begin{array}{c}\text { e5 (Larutan Asam Sitrat dan } \\
\text { Asam Asetat) }\end{array}$ & $2,535 \mathrm{e}$ \\
\hline $\begin{array}{c}\text { e6 (Larutan Asam Tartrat dan } \\
\text { Asam Asetat) }\end{array}$ & $1,947 \mathrm{~d}$ \\
\hline
\end{tabular}

Antosianin merupakan senyawa turunan dari flavillium cation dan intinya kekurangan elektron sehingga sangat reaktif terhadap perubahan lingkungan termasuk perubahan $\mathrm{pH}$ dan suhu (Stanciu et.al., 2010).

Sifat pigmen antosianin umumnya bersifat asam dan lebih stabil dalam kondisi asam. Keadaan yang semakin asam apalagi mendekati $\mathrm{pH} 1$ akan menyebabkan semakin banyaknya pigmen antosianin berada dalam bentuk kation flavilium atau oksonium yang berwarna.

Tingkat keasaaman atau $\mathrm{pH}$ merupakan indikator yang menentukan tingkat alkali dari bahan pangan. Berbedanya jenis pengekstrak juga berpengaruh terhadap tingkat keasaman $(\mathrm{pH})$ yang dipengaruhi oleh ion $\mathrm{H}+$ yang terdapat di dalam pelarut. Ion $\mathrm{H}+$ yang dilepaskan dengan penambahan bahan pengekstrak (berbagai jenis asam) ke dalam pelarut (aquades) diduga berbeda akibat perbedaan derajat disosiasi masingmasing bahan pengekstrak sehingga $\mathrm{pH}$ ekstrak berbeda. Semakin banyak ion $\mathrm{H}+$ yang dilepaskan maka derajat keasaman atau $\mathrm{pH}$ larutan semakin rendah.

Perbedaan $\mathrm{pH}$ tersebut akan memberikan perbedaan daya atau kemampuan pelarut dalam melarutkan zat terlarut dan akan memberikan pengaruh terhadap larutnya senyawa fungsional yang ada di dalam kulit buah naga merah. (Tensiska, 2007)

\section{Kadar Air}

Kadar air merupakan karakteristik kimia yang sangat berpengaruh pada bahan pangan karena dapat mempengaruhi kenampakan, tekstur, dan cita rasa makanan. Kadar air dapat mempengaruhi sifat-sifat fisik seperti kekerasan. (Sudarmadji, 2010)

Berdasarkan hasil analisis variansi (ANAVA) menunjukkan bahwa bahan pengekstrak tidak berpengaruh terhadap kadar air ekstrak senyawa fungsional kulit buah naga merah. Dapat dilihat pada Tabel 8.

Tabel 8. Analisis Variansi Kadar Air

\begin{tabular}{|l|c|c|c|c|c|}
\hline $\begin{array}{c}\text { Sumber } \\
\text { Variansi }\end{array}$ & $\begin{array}{c}\text { Derajat Bebas } \\
(\mathrm{db})\end{array}$ & $\begin{array}{c}\text { Jumlah } \\
\text { Kuadrat (JK) }\end{array}$ & $\begin{array}{c}\text { Kuadrat } \\
\text { Tengah }(\mathrm{KT})\end{array}$ & F Hitung & $\begin{array}{c}\text { F Tabel } \\
5 \%\end{array}$ \\
\hline Kelompok & 3 & 0,001 & 0,0002 & & \\
\hline Perlakuan & 5 & 0,001 & 0,0002 & $0,67^{\text {th }}$ & 2,90 \\
\hline Galat & 15 & 0,004 & 0,0003 & & \\
\hline Total & 23 & 0,006 & & & \\
\hline
\end{tabular}

Diperoleh bahwa penambahan bahan pengekstrak tidak berpengaruh nyata terhadap kadar air ekstrak. Hal tersebut disebabkan karena penambahan konsentrasi asam yang sama tidak akan mempengaruhi kandungan air yang terdapat dalam bahan.

Menurut Sri (2012), konsentrasi asam yang semakin tinggi menyebabkan kadar air yang cenderung menurun. Hal ini disebabkan karena asam yang ditambahkan menyebabkan terjadinya proses difusi atau perpindahan partikel zat padat atau gas dari yang lebih pekat ke kurang pekat. Semakin banyak penambahan asam maka semakin banyak air yang terdapat dalam bahan keluar sehingga air yang terserap oleh bahan semakin sedikit.

\section{Kadar Vitamin C}

Vitamin $\mathrm{C}$ merupakan suatu antioksidan yang larut dalam air, dengan rumus molekul $\mathrm{C}_{6} \mathrm{H}_{8} \mathrm{O}_{6}$ yang diketahui memiliki aktivitas antioksidan yang besar karena bersifat sebagai reduktor. Sifat reduktor tersebut disebabkan oleh mudah terlepasnya atom - atom hidrogen pada gugus hidroksil $(-\mathrm{OH})$ yang terikat pada atom C2 atau C3 (atom - atom pada ikatan rangkap), sehingga radikal bebas dapat dengan mudahnya menangkap dan membentuk radikal bebas tereduksi yang stabil. (Soewoto, 2001)

Berdasarkan hasil analisis variansi (ANAVA) menunjukkan bahwa bahan pengekstrak berpengaruh nyata terhadap kadar vitamin $\mathrm{C}$ ekstrak senyawa fungsional kulit buah naga merah. Hasil uji lanjut duncan dapat dilihat pada Tabel 9. 
Tabel 9. Pengaruh Bahan Pengekstrak Terhadap Kadar Vitamin C

\begin{tabular}{|c|c|}
\hline Bahan Pengekstrak & $\begin{array}{c}\text { Rata-Rata Kadar } \\
\text { Vitamin C (mg/100 g } \\
\text { sampel) }\end{array}$ \\
\hline e1 (Larutan Asam Sitrat) & $110,56 \mathrm{a}$ \\
\hline e2 (Larutan Asam Tartrat) & $167,63 \mathrm{~b}$ \\
\hline e3 (Larutan Asam Asetat) & $117,70 \mathrm{a}$ \\
\hline $\begin{array}{c}\text { e4 (Larutan Asam Sitrat dan } \\
\text { Asam Tartrat) }\end{array}$ & $156,93 \mathrm{~b}$ \\
\hline $\begin{array}{c}\text { e5 (Larutan Asam Sitrat dan } \\
\text { Asam Asetat) }\end{array}$ & $92,73 \mathrm{a}$ \\
\hline $\begin{array}{c}\text { e6 (Larutan Asam Tartrat dan } \\
\text { Asam Asetat) }\end{array}$ & $149,80 \mathrm{~b}$ \\
\hline
\end{tabular}

Berdasarkan Tabel 9, diperoleh bahwa bahan pengekstrak berpengaruh nyata terhadap kadar vitamin $\mathrm{c}$ ekstrak senyawa fungsional kulit buah naga. Kadar vitamin $\mathrm{C}$ pada ekstrak mengalami penurunan akibat pada saat proses perlakuan terutama pengeringan, vitamin $\mathrm{C}$ akan mengalami kerusakan yang disebabkan oleh oksidasi vitamin $\mathrm{C}$ menjadi asam dehidroaskorbat, kemudian oksidasi yang lebih lanjut akan menghasilkan asam diketoglutonat yang menyebabkan vitamin $\mathrm{C}$ kehilangan aktivitasnya.

Menurut Harris (1989), stabilitas asam askorbat akan meningkat dengan menurunnya nilai $\mathrm{pH}$. Vitamin $\mathrm{C}$ bersifat stabil dalam media asam, tetapi pada media netral dan basa sangat mudah terdegradasi oleh panas. Laju degradasi asam askorbat sebanding dengan konsentrasi oksigen terlarut dalam bahan pangan. Sehingga pada ekstraksi dengan penambahan larutan asam tartrat (rata-rata $\mathrm{pH}$ 0,73) menunjukkan bahwa kadar vitamin $\mathrm{C}$ lebih tinggi dibandingkan kelima perlakuan lainnya. Semakin tinggi kadar vitamin C maka semakin tinggi pula kemampuan untuk menghambat reaksi oksidasi yang terjadi.

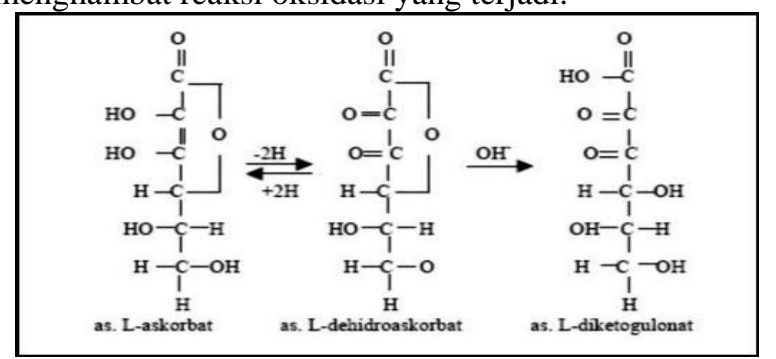

Gambar 1. Oksidasi Asam L-askorbat

\section{Aktivitas Antioksidan}

Metode DPPH merupakan salah satu cara untuk mengukur daya antioksidan suatu senyawa secara langsung. Dasar dari metode ini adalah penstabilan suatu radikal bebas sintesis, yaitu reagen DPPH dengan penangkapan hidrogen dari suatu senyawa antioksidan. DPPH yang merupakan radikal bebas akan stabil karena satu elektron bebasnya mendapatkan pasangan. (Cholisoh dan Utami, 2008)

Berdasarkan hasil analisis variansi (ANAVA) menunjukkan bahwa bahan pengekstrak berpengaruh nyata terhadap aktivitas antioksidan ekstrak senyawa fungsional kulit buah naga merah. Hasil uji lanjut duncan dapat dilihat pada Tabel 10.

Tabel 10. Pengaruh Bahan Pengekstrak Terhadap Aktivitas Antioksidan

\begin{tabular}{|c|c|}
\hline Bahan Pengekstrak & $\begin{array}{c}\text { Rata-Rata Kadar } \\
\text { Aktivitas Antioksidan } \\
\text { (ppm) }\end{array}$ \\
\hline e1 (Larutan Asam Sitrat) & $17.597,42 \mathrm{c}$ \\
\hline e2 (Larutan Asam Tartrat) & $10.242,83 \mathrm{a}$ \\
\hline e3 (Larutan Asam Asetat) & $16.044,72 \mathrm{bc}$ \\
\hline $\begin{array}{c}\text { e4 (Larutan Asam Sitrat dan } \\
\text { Asam Tartrat) }\end{array}$ & $12.100,34 \mathrm{a}$ \\
\hline $\begin{array}{c}\text { e5 (Larutan Asam Sitrat dan } \\
\text { Asam Asetat) }\end{array}$ & $13.677,47 \mathrm{ab}$ \\
\hline $\begin{array}{c}\text { e6 (Larutan Asam Tartrat dan } \\
\text { Asam Asetat) }\end{array}$ & $17.586,26 \mathrm{c}$ \\
\hline
\end{tabular}

Perbedaan aktivitas antioksidan pada produk diduga berkaitan erat dengan perbedaan tetapan disosiasi dari masing - masing bahan pengekstrak. Asam tartrat memiliki tetapan disosiasi yang lebih besar dibandingkan asam sitrat dan asam asetat berturut turut adalah 9,04 x 10-4; 7,21 x 10-4; dan 1,75 x 10-5. (Vogel, 1985)

Semakin besar tetapan disosiasi semakin kuat suatu asam karena semakin besar jumlah ion hidrogen yang dilepaskan ke dalam larutan. Ketika suatu larutan DPPH dicampurkan dengan senyawa yang dapat memberikan atom hidrogen, molekul DPPH akan tereduksi yang ditandai dengan berubahnya warna ungu menjadi kuning. Interaksi antara antioksidan dengan DPPH dapat berupa transfer elektron atau donor hidrogen, kedua interaksi tersebut akan menetralkan radikal bebas. Parameter yang digunakan untuk menginterpretasikan hasil pengujian aktivitas antioksidan adalah nilai Inhibition Concentration 50\% (IC50). (Chang et.al., 2007)

Nilai IC50 menggambarkan besarnya konsentrasi dari ekstrak uji yang dapat menangkap radikal bebas sebesar 50\% melalui persamaan garis regresi linier yang menyatakan hubungan antara konsentrasi senyawa (sampel) uji (X) dengan aktivitas penangkap radikal rata - rata (Y) dari seri replikasi pengukuran. Semakin kecil nilai IC50 nya maka senyawa uji tersebut mempunyai keefektifan sebagai penangkap radikal lebih baik. (Cholisoh dan Utami, 2008)

Aktivitas antioksidan diukur dengan menghitung jumlah pengurangan intensitas warna ungu DPPH. Perendaman yang dilakukan dihasilkan oleh bereaksinya molekul Difenil Pikril Hidrazil dengan atom hidrogen yang dilepaskan hingga membentuk molekul Difenil Pikril Hidrazin dan menyebabkan terjadinya peluruhan warna DPPH dari ungu ke kuning. Adanya penurunan nilai absorbansi DPPH yang diberi sampel terhadap kontrol mempunyai arti bahwa telah terjadinya penangkapan radikal DPPH oleh sampel, dengan penangkapan radikal tersebut mengakibatkan 
ikatan rangkap diazo pada DPPH berkurang sehingga terjadinya penurunan absorbansi. Dari data pengukuran nilai absorbansi dapat dianalisis pengaruh konsentrasi sampel dengan presentase inhibisi dimana peningkatan aktivitas sebanding dengan bertambahnya konsentrasi.

Selama proses pengolahan, aktivitas antioksidan juga dapat mengalami penurunan karena merupakan senyawa yang rentan teroksidasi dengan adanya efek cahaya, panas, logam peroksida, atau secara langsung bereaksi dengan oksigen.

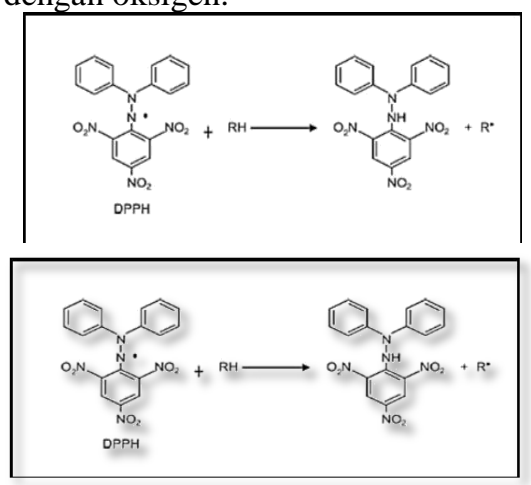

Gambar 2. Reaksi DPPH dan Aktioksidan Asam tartrat yang memiliki tetapan disosiasi yang lebih besar dibandingkan tetapan disosiasi asam lainnya, sehingga jumlah ion hidrogen yang dilepaskan juga besar. Hal tersebut menyebabkan semakin banyaknya DPPH yang ditangkap, maka semakin baik antioksidan tersebut dalam menghambat oksidasi. (Hue, 2012)

Berdasarkan hasil tersebut dapat disimpulkan bahwa ekstrak dengan penambahan asam tartrat lebih efektif dalam mencegah radikal bebas dibandingkan dengan ekstrak lainnya karena pada konsentrasi $10.242,83 \mathrm{ppm}$ sudah mampu menangkap radikal bebas sebesar 50\%.

Tabel 11. Kekuatan Antioksidan

\begin{tabular}{|c|c|}
\hline Intensitas & Nilai IC $_{50}$ \\
\hline Sangat Kuat & $<50 \mathrm{mg} / \mathrm{L}$ \\
\hline Kuat & $50-100 \mathrm{mg} / \mathrm{L}$ \\
\hline Sedang & $100-150 \mathrm{mg} / \mathrm{L}$ \\
\hline Lemah & $>150 \mathrm{mg} / \mathrm{L}$ \\
\hline
\end{tabular}

Berdasarkan tabel 11, aktivitas antioksidan pada ekstrak senyawa fungsional kulit buah naga masih tergolong ke dalam antioksidan yang lemah karena untuk mencegah radikal bebas sebesar $50 \%$ dibutuhkan lebih dari $150 \mathrm{mg} / \mathrm{L}$.

Berdasarkan hasil penelitian diperoleh kesimpulan sebagai berikut :

1. Hasil metode maserasi terpilih dari penelitian pendahuluan adalah metode maserasi biasa serta hasil analisis bahan baku yang meliputi kadar vitamin C sebesar 184,937 mg vitamin $\mathrm{C} / 100$ gram sampel; analisis zat warma dimana nilai $\mathrm{L}^{*} 37,56 \mathrm{a}^{*}$ 9,29 $\mathrm{b}^{*}$ 0,31; serta tingkat keasaman ( $\mathrm{pH}) 4,73$.

2. Bahan pengekstrak berpengaruh nyata terhadap rendemen, zat warna, tingkat keasaman $(\mathrm{pH})$, kadar vitamin $\mathrm{C}$, dan aktivitas antioksidan, tetapi tidak berpengaruh nyata terhadap kadar air.

3. Hasil penelitian utama terhadap ekstrak senyawa fungsional kulit buah naga merah yang terpilih secara keseluruhan respon adalah perlakuan e2 (larutan asam tartrat $2 \%(\mathrm{w} / \mathrm{v})$ ) yang memiliki nilai rendemen 19,09\%; analisis zat warna dengan nilai $\mathrm{L} * 48,12$ a* 31,02 dan nilai $b^{*} 2,70$; tingkat keasaman $(\mathrm{pH})$ 0,73; kadar air 6,3\%; kadar vitamin C 167,63 mg vitamin C/100 gram sampel; serta aktivitas antioksidan sebesar 10.242,83 ppm.

\section{Daftar Pustaka}

1. Andarwulan, N., dan Fitri F. 2012. Pewarna Alami Untuk Pangan. SEAFAST Center. Institut Pertanian Bogor : Bogor.

2. [AOAC] Association of Analytical Chemist Publisher. 1995. Official Methods of Analysis. Washington DC : AOAC Publisher.

3. [AOAC] Association of Official Analytical Chemist. 2005. Official Method of Analysis of The Association of Official Analytical of Chemist International 18th Edition. Maryland, USA: The Association of Official Analytical Chemist International.

4. Chayati, I., Nani R., Titin H. 2011. Teknologi Pengolahan Buah Naga dan Diversifikasi Produk Olahannya Sebagai Upaya Peningkatan Jiwa Kewirausahaan di SMK Agriindustri. Jurnal Inotek Vol. 15 : 2. Universitas Negeri Yogyakarta : Yogyakarta.

5. Cholisoh Z., Utami W. 2008. Aktifitas Penangkap Radikal Ekstrak Ethanol $\mathbf{7 0 \%}$ Biji Jengkol (Archidendron jiringa). PHARMACON. Vol. 9 No. 1. Juni 2008. 33-40. Departemen Kesehatan RI. 1995. Farmakope Indonesia : Jakarta.

6. Fenema OR. 1996. Food chemistry 3rd Edition. New York : Marcel Dekker, Inc.

7. Gaspersz, V. 1995. Teknik Analisis Dalam Penelitian Percobaan. Tarsito : Bandung.

8. Hue S.M., Boyce, A.M., Somasundram, C. 2012. Antioxidant Activity, Phenolic and Flavonoid Contents in The Leaves of Different Varieties of Sweet Potato (Ipomoea batatas). AJCS 6(3) ; 375-380 (2012).

9. Jian, H. 2004. Absorption, Excretion, and Transformation of Individual Anthocyanins in Rats. Thesis. Faculty of Graduate School of The University of Maryland.

10. Putri, N.K.M., I Wayan, G., I Wayan, S. 2015. Aktivitas Antioksidan Antosianin Dalam Ekstrak Etanol Kulit Buah Naga Super Merah (Hylocereus costaricensis) dan Analisis Kadar Totalnya. Jurnal Kimia 9 (2). Jurusan Kimia FMIPA. Universitas Udayana : Denpasar. 243 251 ISSN 1907 - 9850. 
11. Rohanah, A. 2002. Pembekuan. http://www.library.usu.ac.id. Diakses pada 25 Agustus 2017.

12. SNI. 1996. Syarat Mutu Minuman Serbuk. Direktorat Jenderal Badan Pengawasan Obat dan Makanan. SNI 01-4320-1996. Jakarta.

13. Soewoto, H. 2001. Antioksidan Eksogen sebagai Lini Pertahanan Kedua dalam Menanggulangi Peran Radikal Bebas. Bagian Biokimia. Fakultas Kedokteran UI : Jakarta.

14. Sri, N. 2012. Pengaruh Konsentrasi Asam Sitrat Terhadap Karakteristik Ekstrak Pigmen Limbah Selaput Lendir Biji Terung Belanda (Cyphomandra beatacea S.) dan Aktivitas Antioksidannya. Jurusan Ilmu dan Teknologi Pangan. Fakultas Teknologi Pertanian. Universitas Udayana.

15. Sun, Y. and J.J.Cheng. 2005. Dilute Acid Pretreatment of Rye Straw and Bermudagrass for Ethanol Production. Bioresource Technology 96 (14). 1599-1606.

16. Tensiska E., Dita, Natalia. 2007. Ekstraksi Pewarna Alami Dari Buah Arben (Rubus idaeus Linn.) dan Aplikasinya Pada Sistem Pangan. Jurnal Teknologi dan Industri Pangan. Vol. 18 No. 1. Jurusan Teknologi Industri Pangan. Fakultas Teknologi Industri Pertanian. Universitas Padjajaran : Bandung.

17. Trinita, W., Yanuar I. 2014. Analisis Kuantitatif Bahan Pewarna. Pendidikan Teknologi Agroindustri. Universitas Pendidikan Indonesia : Bandung. 